\title{
REVIEW OF IN LIVING MEMORY, STATE RECORDS GALLERY
}

\begin{abstract}
Victoria Haskins
Victoria Haskins of the School of Humanities and Social Sciences, University of Newcastle, reviews In Living Memory, an exhibition produced by State Records and the NSW Department of Aboriginal Affairs; Designers Alison Page \& Margie Rahmann; Exhibition team: Kirsten Thorpe, Sue Newman, Susan Charlton \& Mervyn Bishop. In Living Memory is presented at the State Records Gallery, Sydney Records Centre, 2 Globe Street (off George Street), The Rocks, Sydney, New South Wales. 8 September 2006 - 30 June 2007. Entry free.
\end{abstract}

This astounding exhibition opened last September at State Records NSW's City reading room. It's a venue where many academic and family historians have spent time over the years. In Living Memory puts on display for the first time the many, many images held by the archives amongst records in its custody from the NSW Aborigines Protection Board (1883-1940) and the Aborigines Welfare Board (1940-1969).

Working with the State Records exhibition team, Indigenous designer Alison Page and her design partner Margie Rahmann have made full use of the foyer of the Sydney Records Centre, creating a well-lit, comfortable, and welcoming space. The historical photographs are complemented by the contemporary work of famed photographer Mervyn Bishop, who introduced the exhibition team to Aboriginal communities around New South Wales and documented the process of consultation with the communities. Two of Bishop's lyrical landscape photographs, taken on the trip between Coonabaraban and Dubbo and printed on standing lampshades, add to the gentle ambience of the exhibition. It is an ambience that the exhibition team and the designers deliberately sought in their intention to open up the archives of the state to those Aboriginal people whose intimate lives were so tightly controlled.

There are approximately 1000 pictures in this collection, and they document an extremely painful history of oppression and racial injustice. There is now a significant body of literature addressing how historians can or might use photographs of colonised people, and more specifically, of Aboriginal people, as well as of how descendants might now utilise them to reclaim their past. If we are to consider the archives of such bodies as the Protection and Welfare Boards as the 'archives of a repressive regime', as Lauren Marsh and Steve Kinnane argue, ${ }^{1}$ we can certainly see these images as an intrinsic and vital part of the panoptical regime of the state government. The question of what is to be done with them is more problematic. It is surprising but these images have always been on 'open access' to researchers. With very little being known about their existence, however, few people have actually seen them before, including those whose own families and communities are depicted.

The background to this exhibition began around eight years ago when Indigenous archivist Kirsten Thorpe began working with records related to Aboriginal people held by State Records. Developing relationships with communities represented in the photographs, she established that the people involved want, above all, to ensure that these images are very carefully managed. The photographs frequently depict Aboriginal people who are deceased, which is a matter of sensitivity in itself, but there are also the issues around the power relationship between the viewer and 
the person or people depicted. So fraught has this issue been that in recent years a number of major museums have become very wary indeed of public exhibitions showing historical photographs of Aboriginal people. The challenge for State Records NSW in finding a way to make these photographs accessible to those to whom they mean the most is not to be underestimated, and it is a tribute to the abilities of the cross-cultural exhibition team, and the generosity of the Aboriginal communities they consulted, that this exhibition has come to be. But on top of that, they have managed to pull together a truly stunning and unique exhibition.

Here you are in a safe, and friendly environment: the lamps with the sunset photographs, the framed images arranged along a wall as if they were on a mantelpiece in someone's home, a writing desk at one end of the room, the comfortable long sofas in the centre, where you are invited to sit and leaf through the old-fashioned photograph albums, all these add to the homely air.

Selected photographs grouped in themes are displayed along the long walls, which included original images from Dawn magazine, a series of wedding portraits taken at the far western NSW reserves in the 1920s and another of men working at Pilliga Mission, children at the governor's visit to Moree in 1954, and images of the Wreck Bay Aboriginal community. The inclusion of additional personal photographs, such as Mervyn Bishop's hand-tinted version of his grandmother's wedding photo, give the non-Indigenous viewer a powerful reminder of the highly personal nature of these images.

The heart of the exhibition resides in the beautiful, old-fashioned albums displayed on a central plinth. They separately feature, among other aspects of government control, the three major institutions for Aboriginal children in NSW in the twentieth century, the Kinchela Home for Boys, the Cootamundra Aboriginal Girls' Training Home, and the Bomaderry Home (a mission-run institution for Aboriginal infants). Sitting quietly in this room and turning the pages of the albums is to enter another world. So many different individuals, many of them children, make a vivid, poignant, unforgettable statement about the impact of government control upon real people.

In fact, the albums are the link to the exhibition's reason for being, a database of the Protection/Welfare Board images on computers in the room, searchable by subject, surname, first name, place, and/or year. All the photographs have been digitised and can be found and ordered via this database. Susan Charlton explained that the albums were not provided so much for aesthetic effect, but because they are user-friendly: you can sit and look through the albums till you find an image of somebody or something meaningful to you, then search the computers and order a copy (cost: \$1 per A4 copy, posted to you). The database, however, cannot be accessed off-site. In this way, the exhibition team has sought to make the photographic collection easily accessible to Aboriginal and other visitors, without exposing the images worldwide via the internet.

With virtually no overt commentary of the nature some might like to call 'political correctness', the exhibition itself evokes a powerful mixture of feelings. The exhibition team and the designers are well attuned to the complexities of displaying these photographs and by challenging any impulse to simplistic interpretation, the people displayed are neither victimised nor lionised, but instead, their humanity is celebrated. Visitors recording their impressions in the guestbook are uniformly touched and inspired, and the comments I have also heard personally from Aboriginal visitors have been positive: 'Angry, joyful, and proud all at once'. 
Some of the photographs have been reproduced in a special issue of the State Records newsletter, Vital Signs, no. 9, September 2006, ${ }^{2}$ which will give you a tantalising glimpse of the wider exhibition. But whether you are interested in Aboriginal and Australian histories, in photography and colonisation, or simply appreciate exhibitions that strongly connect with their audience, it is worth making a special effort to see In Living Memory.

\section{ENDNOTES}

1 See (with regard to the West Australian records) Lauren Marsh and Steve Kinnane, 'Ghost Files: The Missing Files of the Department of Indigenous Affairs Archives'; Christine Choo and Shawn Hollbach (eds) History and Native Title: Studies in Western Australian History 23. Perth: University of Western Australia, 2003: 113-114.

2

Available online at http://www.records.nsw.gov.au/staterecords/vital_signs_9_11032.asp. 